\title{
PENGEMBANGAN ALAT PERAGA PAPAN BERPAKU MATEMATIKA KELAS III SDN 29 SUNGAI PUANG
}

\author{
Anita Sri Rejeki Hutagaol ${ }^{1}$, Heronimus Nyama ${ }^{2}$, Warkitin ${ }^{3}$ \\ 1,2,3 STKIP Persada Khatulistiwa Sintang, Jl. Pertamina-Sengkuang-Sintang \\ e-mail: ${ }^{1}$ boruhutagaolbest @ gmail.com, ${ }^{2}$ heronimus1004@gmail.com, \\ warkintin-1984@yahoo.co.id
}

\begin{abstract}
This study aims to develop a geaboard props with descriptive procedural: 1) potential and problems, 2) data collection, 3) media design, 4) media validation, 5) media revision, 6) media trial, 7) media revision, 8) trial use, 9) media revision and 10) geaboard props. The results of the research are: 1) media validation by media experts obtained all scores of 75 in the good category and validation by material experts obtained an average of 98 with a very good category so that the geaboard props media is included in the very feasible category. So it can be concluded that the geaboard teaching aids are very suitable to be used for material in finding square and rectangular area.
\end{abstract}

Keyword: Development, Geaboard

\begin{abstract}
Abstrak. Penelitian ini bertujuan untuk mengembangkan alat peraga papan berpaku dengan procedural bersifat diskriptif diantaranya: 1) potensi dan masalah, 2) pengumpulan data, 3) disain media, 4) validasi media, 5) revisi media, 6) uji coba media, 7) revisi media, 8) uji coba pemakaian, 9) revisi media serta 10) produk alat peraga papan berpaku. Hasil penelitian berupa : 1) validasi media oleh ahli media diperoleh semua skor 75 dengan kategori baik dan validasi oleh ahli materi diperoleh rerata 98 dengan kategori sangat baik sehingga media alat peraga papan berpaku termasuk dalam kategori sangat layak. Sehingga dapat disimpulkan alat peraga papan berpaku sangat layak digunakan untuk materi mencari luas persegi dan persegi panjang.
\end{abstract}

Kata Kunci: Pengembangan, Papan Berpaku 


\section{PENDAHULUAN}

Matematika merupakan salah satu bidang studi yang mendukung ilmu pengetahuan dan teknologi. Namun sampai saat ini masih banyak siswa yang merasa matematika sebagai mata pelajaran yang sulit, tidak menyenangkan, bahkan momok yang menakutkan. Namun demikian harus mempelajarinya karena merupakan sarana untuk pemecahan masalah sehari-hari (Marti dalam Sundayana 2015:2). Dengan kemampuan guru dalam menggunakan metode ataupun media yang ada maka guru juga bisa memfasilitasi siswa dengan kompetensi yang dimiliki oleh guru.

Guru sebagai pendidik dituntut untuk memfasilitasi pembelajaran supaya kegiatan belajar mengajar dapat tercapai di kelas. Selain menyiapkan materi pembelajaran, guru juga dituntuttuntuk mengerti kebutuhan siswa mengingat bahwa pada kelas III masih memiliki kesulitan dalam belajar secara abstrak sehingga berdampak pada hasil belajar.

Menurut Sudjana (2011:28) Hasil belajar adalah suatu proses yang ditandai dengan adanya perubahahan pada diri seseorang. Perubahan sebagai hasil proses belajar dapat ditunjukkan dalam berbagai bentuk seperti berubah pengetahuannya, pemahamannya, sikap dan tingkah lakunya, serta keterampilannya. Lebih lanjut Sudjana (2011:32) mengatakaan bahwa "Penilaian proses hasil belajar adalah upaya memberi nilai terhadap kegiatan belajar mengajar yang dilakukan oleh siswa dan guru dalam mencapai tujuan pengajaran".
Namun pada kenyataannya, berdasarkan obeservasi awal dan wawancara yang dilakukan peneliti, pelaksanaan pembelajaran yang dilakukan di SDN 29 Sungai Puang terutama di kelas III yang jumlahnya 21 orang nilai KKM yang diharapkan yaitu 60 belum sesuai dengan kompetensi yang diharapkan. Terdapat 9 orang yang mencapai KKM 60, sedangkan 12 orang belum mencapai KKM. Hal ini terlihat dari hasil ulangan harian pada materi bangun datar, siswa kesulitan dalam menentukan luas bangun datar.

Temuan tersebut membuktikan bahwa hasil belajar siswa masih rendah. Faktor yang menyebabkan rendahnya hasil belajar tersebut dikarenakan: (1) siswa kurang perhatian terhadap mata pelajaran matematika, (2) siswa merasa bosan terhadap pelajaran matematika, serta (3) media kurang bervariasi sehingga siswa kurang jelas dengan materi yang diberikan, bahkan penggunaan media/ alat peraga masih sangat jarang digunakan oleh guru. Hal tersebut sesuai dengan pendapat Hutagaol dan Rismawati (2019:4) keberhasilan proses belajar proses belajar siswa dipengaruhi oleh dua faktor yaitu faktor internal dan faktor eksternal. Faktor internal meliputi kecerdasan, bakat, minat, perhatian orang tua, motivasi, kesehatan jasmani, dan cara belajar siswa itu sendiri. Faktor eksternal meliputi keluarga, lingkungan, guru, masyarakat, sekolah, serta media pembelajaran.

Wibowo dalam Sundayana (2015: 30) menyampaikan terdapat tujuh alasan guru tidak menggunakan media pembelajaran yaitu: (1) Menggunakan media dianggap merepotkan 
guru (2) Media pembelajaran yang digunakan harus canggih dan mahal (3) Tidak bisa membuat media pembelajaran sendiri (4) Media pembelajaran hanya dianggap sebagai hiburan (membuat siswa hanya bermain-main dan membuat pembelajaran menjadi tidak serius), sedangkan belajar itu serius (5) Tidak tersedia media pembelajaran di sekolah (6) Kebiasaan menikmati ceramah atau bicara (7) Kurangnya penghargaan dari atasan.

Mengingat siswa belum jelas dan kurang tertarik dengan materi yang disampaikan, maka dalam proses pembelajaran menurut Sri Rejeki (2016:6) Pengembangan perangkat pembelajaran merupakan tanggungjawab guru di sekolah, karena dengan kreativitas guru dalam mengembangkan perangkat pembelajaran akan menghasilkan kegiatan pembelajaran yang bermakna. Perangkat pembelajaran satu diantaranya adalah alat peraga. Alat peraga tersebut mampu mewakili penjelasan guru sehingga peserta didik bisa belajar secara mandiri. Alat peraga diharapkan mampu untuk menjelaskan materi yang disampaikan.

Kemp dan Dayton dalam Sundayana (2015: 3) mengatakan bahwa "Media atau alat peraga dalam pembelajaran memberikan kontribusi sebagai: penyampaian pembelajaran dapat lebih terstandar, pembelajaran dapat lebih menarik, waktu penyampaian pembelajaran dapat diperpendek, kualitas pembelajaran dapat ditingkatkan, proses pembelajaran dapat berlangsung kapanpun dan dimanapun diperlukan, sikap positif siswa terhadap materi pembelajaran dapat ditingkatkan, dan peran guru berubah kearah yang positif".

Media berasal dari bahasa latin medius merupakan bentuk jamak dari kata medium yang secara harfiah berarti perantara atau pengantar Arsyad (1996:3). Sundayana (2015: 4) menuliskan secara lebih khusus, pengertian media dalam proses belajar mengajar cenderung diartikan sebagai alat- alat grafis, fotografis, atau elektronis untuk menangkap, memproses dan menyusun kembali informasi visual dan verbal". Dapat disimpulkan bahwa media pembelajaran adalah segala sesuatu yang dapat menyampaikan dan menyalurkan pesan dari sumber secara terencana sehingga tercipta lingkungan belajar yang kondusif dimana penerimanya dapat melakukan proses belajar secara efisien. Alat peraga Matematika bermacam-macam salah satunya papan berpaku.

Papan berpaku dapat membantu pemahaman konsep pada peserta didik terutama pada konsep bangun datar. Pada papan ini dibuat bujursangkar-bujursangkar kecil yang pada setiap titik sudutnya ditancapkan paku setengahnya masuk dan setengah lagi masih tampak/timbul. Papan berpaku sangat praktis, baik untuk peserta didik dan guru mengajar. Selain praktis papan berpaku ini dapat dibuat sendiri oleh guru, dan tidak memerlukan biaya yang terlalu banyak dalam pembuatannya.

Papan berpaku merupakan salah satu media pembelajaran di sekolah dasar yang digunakan untuk menanamkan konsep/ pengertian geometri seperti pengenalan 
bentuk-bentuk bangun datar, dan menghitung luas bangun datar. Dengan menggunakan alat peraga papan berpaku diharapkan siswa dapat lebih memahami lagi materi bangun datar dalam menentukan luas persegi dan persegi panjang. Siswa tidak lagi menganggap matematika sebagai mata pelajaran yang sangat menyulitkan dan memerlukan banyak berpikir sehingga menimbulkan rasa kantuk.

Berdasarkan latar belakang masalah yang telah diuraikan maka peneliti merasa tertarik untuk melakukan penelitian tentang"Pengembangan Alat Peraga Papan Berpaku Matematika Siswa Kelas III SDN 29 Sungai Puang “

Tujuan dalam penelitian adalah untuk mengembangan alat perga papan berpaku yang bisa digunakan untuk menemukan luas persegi dan persegi panjang pada pelajaran matematika materi bangun datar siswa kelas III SDN 29 Sungai Puang.

\section{METODE}

Penelitian ini merupakan jenis penelitian pengembangan atau dalam bahasa Inggrisnya Research and Development (R\&D), yang artinya metode penelitian yang digunakan untuk menghasilkan produk tertentu dan menguji keefektifan produk tersebut (Sugiyono 2013: 407). Desain penelitian ini mengacu pada model Sugiyono (2013: 409) dengan langkah- langkah sebagai berikut: Potensi Dan Masalah, Pengumpulan Data, Desain Produk, Validasi Desain, Uji Coba Produk, Revisi Produk, Uji Coba Pemakaian, Revisi Produk dan Produksi Masal.
Uji coba pada siswa diambil siswa kelas III SDN 29 Sungai Puang, tahun pelajaran 2016/2017 yang terdiri dari 21 siswa. Teknik pengambilan subjek dalam penelitian ini menggunakan teknik Sampling Jenuh dimana pada sampling jenuh adalah teknik penentuan subjek bila semua anggota digunakan sebagai sampel Sugiyono (2013: 85). Subjek uji coba penelitian ini adalah siswa kelas III SDN 29 Sungai Puang. Lokasi penelitian ini adalah SDN 29 Sungai Puang, terletak di Desa Kayu Dujung, Kecamatan Ketungau Tengah, Kabupaten Sintang.

Teknik Analisis Data menggunakan statististik deskripsi, data yang dihasilkan dari penelitian ini berupa data kualitatif. Data kualitatif adalah tanggapan-tanggapan dari para ahli terhadap kualitas produk yang dikembangkan ditinjau dariaspek materi dan media. Statistic yang digunakan adalah statistic deskriptif, menurut Sugiyono (2014:29) statistic deskriptif adalah statistik yang digunakan untuk menggambarkan atau menganalisis suatu hasil penelitian, tetapi tidak digunakan untuk membuat kesimpulan yang lebih luas .

Menurut Sukardi (2003: 50) untuk instrumen dalam bentuk nontes kriteria penilaian menggunakan kritria yang ditetapkan berdasarkan jumlah butir valid dan nilai yang dicapai dari skala nilai yang digunakan, oleh karena itu kriteria penilaian produk alat peraga papan berpaku ini didasarkan pada kiteria yang disusun dengan cara melakukan pengelompokkan skor (interval nilai) yang didapat dari validator. 
Kriteria penilaian untuk para ahli di dalam penelitian ini disusun dengan cara pengelompokkan skor (interval nilai) setelah diperoleh pengukuran dari tabulasi skor. Langkah-langkah perhitungannya adalah sebagai berikut :

1) Menentukan kelas interval, yakni 2 karena membutuhkan jawaban yang pasti dengan menggunakan skala Guttman .

2) Menentukan rentang skor, yaitu rentang skor maksimum dikurangi skor minimum.

3) Menentukan panjang kelas (P), yaitu rentang skor dibagi jumlah kelas.

4) Menyusun kelas interval dimulai dari skor terkecil sampai skor terbesar. Untuk lebih jelasnya dapat dilihat pada tabel berikut :

Tabel 1 Kriteria Kualitas Instrumen

\begin{tabular}{cc}
\hline Kualitas & Interval Skor \\
\hline Layak dan andal & $3 \leq 4$ \\
\hline Tidak layak dan tidak andal & $1 \leq 2$ \\
\hline Berdasarkan penelitian & ini untuk
\end{tabular}

mengukur kualitas alat peraga papan berpaku sama dengan menentukan kelayakan dari media pembelajaran tersebut, yaitu diperlukan jumlah butir soaldan skala nilai. Hasil perkalian jumlah butir soal dikalikan nilai tertinggi diperoleh skor maksium, sedangkan dari perkalian jumlah butir valid dari nilai terendah diperleh skor minimum

Tabel 2 Krieria Kelayakan Media

\begin{tabular}{cc} 
Kategori Penilaian & Interval Nilai \\
\hline Sangat Baik & $80 \leq 100$ \\
\hline Baik & $60 \leq 80$ \\
\hline Cukup & $40 \leq 60$ \\
\hline Kurang & $20 \leq 40$ \\
\hline Sangat Kurang & $0 \leq 20$
\end{tabular}

Tabel 3 Interprestasi Kategori Penilaian Hasil Validasi Para Ahli

\begin{tabular}{llr} 
Kategori & \multicolumn{2}{c}{ Interprestasi } \\
Penilaian & \multicolumn{1}{c}{ materi, Ahli media } \\
\hline Layak & $\begin{array}{l}\text { Ahli matak bahwa alat peraga } \\
\text { menyatakan } \\
\text { papan berpaku baik digunakan } \\
\text { untuk proses pembelajaran. }\end{array}$ \\
\hline Tidak & $\begin{array}{l}\text { Ahli materi dan Ahli media } \\
\text { menyatakan bahwa alat peraga } \\
\text { layak } \\
\text { papan tidak baik digunakan untuk } \\
\text { proses pembelajaran. }\end{array}$ \\
\hline
\end{tabular}

Untuk peserta didik dalam melakukan perhitungan menggunakan langkah-langkah sebagai berikut :

1. Menentukan jumlah kelas interval, yakni 4 dengan menggunakan skala Likert, karena untuk memperoleh pendapat dari peserta didik.

2. Menentukan rentang skor, yaitu rentang skor maksimum dikuragi skor minimum.

3. Menentukan panjang kelas $(\mathrm{P})$, yaitu rentang skor dibagi jumlah kelas.

4. Menyusun kelas interval dimulai dari skor terkecil sampai skor terbesar.

Tabel 4 Kriteria Kualitas Media

\begin{tabular}{cc} 
Kategori Penilaian & Interval Nilai \\
\hline Sangat Baik & $80 \leq 100$ \\
\hline Baik & $60 \leq 80$ \\
\hline Cukup & $40 \leq 60$ \\
\hline Kurang & $20 \leq 40$ \\
\hline Sangat Kurang & $0 \leq 20$ \\
\hline
\end{tabular}


Tabel 5 Interpretasi Kategori Penilaian Hasil Uji Coba Kelompok Kecil

\begin{tabular}{ll}
$\begin{array}{l}\text { Kategori } \\
\text { Penilaian }\end{array}$ & \multicolumn{1}{c}{ Interpretasi } \\
\hline $\begin{array}{l}\text { Sangat } \\
\text { Setuju }\end{array}$ & $\begin{array}{l}\text { Peserta didik sangat memahami } \\
\text { materi dan sangat tertarik dengan } \\
\text { alat peraga papan berpaku }\end{array}$ \\
\hline Setuju & $\begin{array}{l}\text { Peserta didik memahami materi dan } \\
\text { tertarik dengan alat peraga papan } \\
\text { berpaku. }\end{array}$ \\
& $\begin{array}{l}\text { Peserta didik kurang memahami } \\
\text { Kurang } \\
\text { Setuju }\end{array}$ \\
& alat peraga papan berpaku. \\
\hline Sangat & Peserta didik tidak memahami \\
Tidak & materi dan tidak tertarik dengan alat \\
Setuju & peraga papan berpaku. \\
\hline
\end{tabular}

Untuk mengetahui kelayakan

diketahui melalui hasil dari perhitungan ratarata dan hasil presentase. Penggunaan presentase (frekuinsi relative) terdapat skor yang diperoleh dimaksudkan sebagai konversi untuk memudahkan dalam menganalisa hasil penelitian.

Pada penelitian pengembangan ini, kelompok skor ditentukan menjadi 4 kategori (4 kelompok skor). Untuk itu diperlukan jumlah butir valid, skala nilai dari 1 - 4 (skala Likert 4) dimana 4 merupakan nilai tertinggi (nilai maxsimum) dari merupakan nilai terendah (minimum). Dari perkalian jumlah butir valid dari nilai terendah (minimum) akan diperoleh skor terendah (minimum) dan dari perkalian jumlah butir valid dengan nilai tertinggi (nilai maxsimum) maka akan kita peroleh skor tertinggi (skor maxsimum).

Selanjutnya dari skor maxsimum sampai skor minimum tersebut kemudian dibagi menjadi 4 kelompok skor (interval nilai) yaitu sangat setuju, setuju, kurang setuju dan sangat sangat tidak setuju. Selain data yang berupa penilaian oleh siswa terhadap kualitas produk yang dikembangkan, juga terdapat data yang berupa skor penilaian unjuk kerja siswa. Data ini digunakan untuk mengukur keefektifan produk yang dikembangkan. Keefektifan adalah suatu pencapaian sasaran yang telah diprogramkan atau ditentukan, bisa juga sebagai perbandingan antara hasil nyata dengan hasil ideal, dengan demikian maka produk alat peraga papan berpaku dalam bangun datar dikatakan efektif apabila berhasil mencapai kriteria yang telah ditentukan.

\section{HASIL DAN PEMBAHASAN}

\section{Hasil}

Berdasarkan hasil dari validasi para ahli diperoleh:

a. Ahli Materi

Tabel 6 Hasil Validasi Oleh Ahli Materi

\begin{tabular}{lll}
\hline \multicolumn{3}{c}{ Komentar/Saran } \\
\hline 1 & $\begin{array}{l}\text { Kalimat yang digunakan masih sangat } \\
\text { kurang }\end{array}$ \\
\hline 2 & $\begin{array}{l}\text { Bahasa yang digunakan masih kurang sesuai } \\
\text { dengan pemahaman siswa Kelas III. }\end{array}$ \\
\hline
\end{tabular}

b. Ahli Media

Tabel 7 Hasil Validasi Ahli Media

\begin{tabular}{cc}
\hline No & Komentar/ Saran \\
\hline 1 & Alat peraga lebih baik diberi bingkai \\
\hline 2 & Alat peraga diberi warna biar menarik. \\
\hline
\end{tabular}

Selanjutnya untuk hasil angket uji coba kelompok kecil dapat dilihat dalam tabel di bawah ini:

Tabel 8 Angket Uji Coba Kelompok Kecil

\begin{tabular}{rccc}
\hline Skor & $\begin{array}{c}\text { Kategori } \\
\text { Pilihan }\end{array}$ & $\begin{array}{c}\text { Interval } \\
\text { Nilai }\end{array}$ & $\begin{array}{c}\text { Prosentase } \\
\text { Hasil }\end{array}$ \\
\hline 4 & Sangat Setuju & $80 \leq 100$ & $94 \%$ \\
\hline 3 & Setuju & $60 \leq 80$ & $6 \%$ \\
\hline 2 & Kurang Setuju & $40 \leq 60$ & $0 \%$ \\
\hline 1 & Tidak Setuju & $20 \leq 40$ & $0 \%$ \\
\hline \multicolumn{3}{c}{ Jumlah } & $\mathbf{1 0 0 \%}$ \\
\hline
\end{tabular}


Untuk hasil dari angket uji coba lapangan dapat dilihat dalam tabel di bawah ini:

Tabel 9 Hasil Angket Uji Coba Lapangan

\begin{tabular}{cccc}
\hline Skor & $\begin{array}{c}\text { Kategori } \\
\text { Pilihan }\end{array}$ & $\begin{array}{c}\text { Interval } \\
\text { Nilai }\end{array}$ & $\begin{array}{c}\text { Prosentase } \\
\text { Hasil }\end{array}$ \\
\hline 4 & Sangat Setuju & $80 \leq 100$ & $92 \%$ \\
\hline 3 & Setuju & $60 \leq 80$ & $8 \%$ \\
\hline 2 & Kurang Setuju & $40 \leq 60$ & $0 \%$ \\
\hline 1 & Tidak Setuju & $20 \leq 40$ & $0 \%$ \\
\hline \multicolumn{5}{c}{ Jumlah } & $\mathbf{1 0 0 \%}$ \\
\hline
\end{tabular}

\section{Pembahasan}

Berdasarkan langkah-langkah penelitian yang telah dikemukakan, maka pengembangan media pembelajaran dilakukan dengan langkah-langkah sebagai berikut:

1. Potensi dan Masalah

Kegiatan ini dilakukan dengan cara observasi kelas dan wawancara dengan guru dan siswa. Berdasarkan hasil wawancara dan observasi dapat diuraikan sebagian besar guru banyak yang hanya menggunakan ceramah saja dalam menyampaikan materi, dari itu siswa banyak yang bingung dan kurang jelas dengan materi yang disampaikan. Kenyataan tersebut berakibat pada hasil belajar siswa tidak sesuai yang diharapkan.

Oleh karena itu, peneliti membuat suatu produk alat peraga pembelajaran yang sederhana yang diharapkan mampu membangkitkan semangat belajar siswa dan mempermudah siswa di dalam menerima materi yang disampaikan.

2. Pengumpulan Data

Tahap yang dilakukan dalam pengumpulan data peneliti menggunakan teknik observasi langsung dan lembar wawancara dengan menggunakan lembar observasi kepada kepala sekolah, guru, dan siswa kelas III. Dari hasil observasi dan wawancara menunjukkan bahwa siswa mengalami kesulitan belajar pada materi mencari luas persegi dan persegi panjang.

3. Desain Produk

Langkah yang ditempuh setelah melakukan pengumpulan data adalah membuat desain produk. Desain produk dilakukan bertujuan untuk mengetahui gambaran tentang produk yang akan dihasilkan dalam pengembangan alat peraga matematika.

Pembuatan alat peraga papan berpaku menggunakan papan triplek dengan ukuran $30 \mathrm{~cm}$ X $20 \mathrm{~cm}$ dan ditancapkan paku disetiap pertemuan garis yang sudah diukur berbentuk kotak satuan dengan jarak $2 \mathrm{~cm}$ tiap garis.

4. Validasi Produk

Berikut hasil validasi produk menurut para ahli dilakukan oleh ahli yangsudah memiliki kompetensi di bidangnya:

\section{1) Ahli Materi}

Berdasarkan kriteria kualitas materiyang digunakan untuk memperjelas alat peraga papan berpaku yang divalidasi oleh ahli materi maka masing-masing yang terdiri dari 10 poin memperoleh nilai $100 \%$ maka Alat peraga papan berpaku "sangat layak digunakan". 
2) Ahli media

Berdasarkan kriteria alat peraga papan berpaku yang divalidasi oleh ahli media maka memperoleh nilai $100 \%$ alat peraga papan berpaku dikatakan "sangat layak digunakan"

5. Revisi Desain

Pedoman revisi produk diperoleh dari saran perbaikan yang dituliskan ahli pada lembar validasi

6. Uji Coba Produk

Uji coba kelompok kecil ini dilaksanakan di SDN 29 Sungai Puang. Uji coba kelompok kecil ini melibatkan 10 siswa (responden) kelas III. 10 siswa dipilih secara random (acak).

Alasan peneliti memilih 10 orang siswa pada uji coba kelompok kecil pada siswa kelas III SDN 29 Sungai Puang adalah ingin melihat langsung respon siswa di sekolah tersebut. Selain itu juga peneliti tidak menerapkan uji coba kelompok kecil ini di sekolah lain dikarenakan kondisi, lingkungan dan faktor dari jabatan guru yang mengajar di SDN 29 Sungai Puang masih berstatus guru Honorer dan tamatan dari SMA. Berikut hasil angket uji coba kelompok kecil dapat dilihat pada gambar 1 .

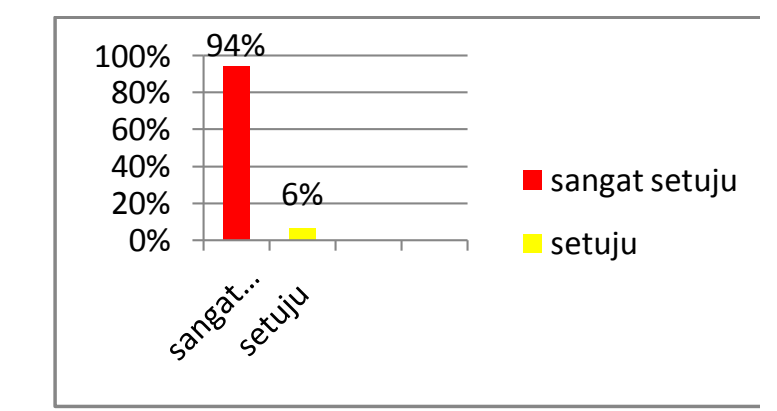

Gambar 1 Hasil Angket Uji Coba Kelompok Kecil
7. Revisi Produk

Tidak terdapat kendala yang ditemui pada saat uji coba kelompok kecil sehingga tidak terdapat revisi produk. Karena pada saat uji coba terbatas data menunjukkan kategori “ Sangat baik”, maka untuk selanjutnya alat dapat diuji cobakan secara luas.

8. Uji Coba Pemakaian

Penilaian alat peraga papan berpaku dengan angket non tes yang terdiri dari 10 soal dengan jumlah responden 21 orang dan dengan tes 5 soal. Berikut hasil angket uji coba lapangan dapat dilihat pada gambar 2 berikut:

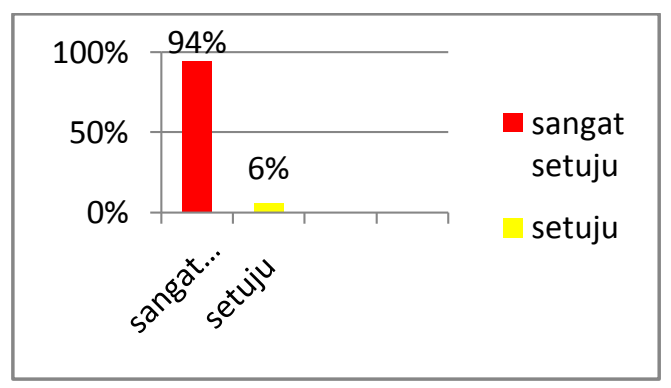

\section{Gambar 2 Hasil Angket Uji Lapangan}

9. Revisi Produk

Pada tahap revisi produk ini alat peraga papan berpaku tidak direvisi atau tidak mengalami perbaikan.

10. Pembuatan Produk Masal (Skala Kecil)

Setelah melalui beberapa tahapan mulai dari pengembangan, validasi, sampai pada uji coba kelompok kecil dan uji lapangan, maka diperoleh hasil akhir alat peraga papan berpaku dengan materi mencari luas persegi dan persegi panjang dapat digunakan dalam proses pembelajaran. 
Alasan peneliti hanya memproduksi alat peraga papan berpaku dalam skala kecil adalah karena hanya digunakan untuk kepentingan sekolah tersebut. Selain itu, alat peraga papan berpaku ini belum bisa diproduksikan secara masal dikarenakan masalah biaya dan alat yang menjadi pendukung dalam pembuatannya.

Penilaian kelayakan alat peraga papan berpaku terdiri atas tiga aspek antara lain pengembangan alat peraga, Hasil Belajar Kognitif, dan Respon sebagai berikut:

1. Pengembangan Alat Peraga Papan Berpaku

Desain produk alat peraga papn berpaku disesuikan dengan kompetensi yang ada pada buku, hal ini dilakukan bertujuan agar siswa lebih mudah cepat memahami materi yang disampaikan. Setelah produk tersebut jadi maka produk tersebut divalidasi oleh ahli, ahli yang memvalidasi pada penelitian ini adalah ahli materi dan ahli media. Saran dari ahli materi dan media itu dilaksanakan pada sesuai dengan saran.

Selanjutnya produk tersebut diuji cobakan pada kelompok kecil, disini siswa yang diambil secara acak 10 orang. Hasil dari angket tersebut sebyak $94 \%$ siswa mengatakan "sangat Setuju" dan 6\% siswa "setuju" Setelah diujicobakan tidak ada saran dari uji coba produk pada kelopok kecil maka selanjutnya akan dilanjutkan pada uji coba lapangan atau uji coba pemakaian yang melibatkan semua siswa kelas III SD Negeri 29 Sungai Puang. Dari hasil uji coba angket siswa adalah 92\% mengatakan "Sanagt Setuju" dan 8\% siswa mengatakan "setuju".

Setelah uji coba pemakaian maka produk tersebut di revisi, namun karena tidak ada saran maka tidak ada perbaikan pada revisi produk ini dan selanjutnya pada tahap produksi Produk Masal, pada tahap ini hanya akan dilakukan dalam skala kecil. mengingat hanya digunakan untuk kepentingan sekolah tersebut saja.

2. Respon terhadap Alat Peraga Papan Berpaku

a. Validasi Desain

1) Ahli Materi

Berdasarkan kriteria kualitas materiyang digunakan untuk memperjelas alat peraga papan berpaku yang divalidasi oleh ahli materi maka masing-masing yang terdiri dari 10 poin memperoleh nilai $100 \%$ maka Alat peraga papan berpaku "sangat layak digunakan"

2) Ahli media

Berdasarkan kriteria alat peraga papan berpaku yang divalidasi oleh ahli media maka memperoleh nilai $100 \%$ alat peraga papan berpaku dikatakan "sangat layak digunakan"

3) Uji coba kelompok kecil

Berdasarkan kriteria kelayakan alat peraga papan berpaku dari uji coba kelompok kecil yang berjumlah 10 orang siswa diperoleh hasil tersebut $94 \%$ siswa mengatakan sangat layak dan $6 \%$ siswa mengatakan layak dan $0 \%$ siswa 
mengatakan kurang layak, maka dapat diartikan bahwa alat peraga papan berpaku termasuk dalam kategori sangat layak digunakan dalam proses belajar mengajar.

4) Uji coba lapangan

Berdasarkan kriteria kelayakan alat peraga papan berpaku dari uji lapangan yang berjumlah 21 orang siswa. Hasil tersebut $92 \%$ siswa mengatakan sangat layak dan 8\% siswa mengatakan layak dan $0 \%$ siswa mengatakan kurang layak, maka dapat diartikan bahwa alat peraga papan berpaku termasuk dalam kategori sangat layak digunkan dalam proses belajar mengajar.

Berdasarkan hasil penelitian di atas hal ini sesuai dengan yang dikatakan Ali (Sundayana, 2013: 7) bahwa alat peraga adalah segala sesuatu yang dapat digunakan untuk menyatakan pesan merangsang pikiran, perasaan dan perhatian dan kemauan siswa sehingga dapat mendorong proses belajar. Ruseffendi (Sundayana, 2015: 7) menyatakan bahwa alat perga merupakan alat yang menerangkan atau mewujudkan konsep matematika. Sedangkan menurut Praudjono (Sundayana, 2013: 7) alat peraga adalah benda konkret yang dibuat, dihimpun atau disusun secara sengaja digunakan untuk membantu menanamkan atau mengembangkan konsep matematika. Sedangkan Sudjana (2011: 59) mengatakan bahwa alat peraga adalah alat yang dapat diserap oleh mata dan telinga dengan tujuan membantu guru agar dalam proses belajar mengajar bisa lebih efektif dan efesien. Menurut Annisah (2014: 2), alat peraga matematika dapat diartikan sebagai suatu perangkat benda konkrit yang dirancang, dibuat, dan disusun secara sengaja yang digunakan untuk membantu menanamkan dan memahami konsep-konsep atau prinsip-prinsip dalam matematika.

\section{SIMPULAN (PENUTUP)}

Penelitian dan pengembangan yang dilakukan menghasilkan produk alat peraga papan berpaku untuk siswa SD kelas III, khususnya mata pelajaran matematika pada materi mencari luas persegi dan persegi panjang. Adapun kesimpulan yang diperoleh:

1. Pengembangan Alat Peraga Papan Berpaku

Di dalam mengembangkan media alat peraga papan berpaku yaitu dengan cara : a) Melakukan analisis kebutuhan yang dilakukan dengan observasi kelas dan wawancara, b) Setelah alat peraga papan berpaku tersusun, maka alat peraga papan berpaku divalidasi oleh para ahli materi dan ahli media. c) Setelah media divalidasi oleh para ahli, selanjutnya merevisi sesuai 
saran. d) Selanjutnya alat peraga papan berpaku diuji cobakan pada kelompk kecil yang berjumlah 10 responden. e) Kemudian alat peraga papan berpaku di ujikan kelapangan supaya produk alat peraga papan berpaku hasilnya maksimal. f) Tahap selanjutnya merevisi sesuai denga saran dari responden uji lapangan, bila hasilnya layak maka alat peraga papan berpaku dapat digunakan dalam proses pembelajaran.g) Media alat peraga papan berpaku ini digunakan oleh guru dalam penyampaian materi dan praktik membuat persegi dan persegi panjang.

2. Respon Siswa Terhadap Alat Peraga Papan Berpaku

Hasil validasi ahli materi dan ahli media termasuk kategori layak dengan presentase $100 \%$. Pada uji coba kelompok kecil kelayakan alat peraga papan berpaku dengan 94\% responden termasuk kategori sangat layak dan $6 \%$ responden termasuk kategori layak dan $0 \%$ responden termasuk kategori kurang layak. Sedangkan pada uji lapangan kelayakan alat peraga papan berpaku dengan $92 \%$ responden termasuk kategori sangat layak dan $8 \%$ responden termasuk kategori layak.

Berdasarkan hasil penelitian tentang pengembangan alat peraga papan berpaku pada mata pelajaran matematika siswa kelas III SDN 29 Sungai Puang”, untuk prospek pengembangan selanjutnya perlu diperhatikan diantaranya, pengembangan alat peraga papan berpaku sebaiknya perlu dipersiapkan lebih matang, mulai dari analisis kebutuhan, penyusunan produk hingga produk akhir agar proses dan hasil pengembangan lebih maksimal dan kualitas alat peraga papan berpaku pada mata pelajaran Matematika yang sudah layak perlu dikembangkan terus, atau diperbaharui pada waktu-waktu tertentu sesuai dengan kebutuhan materi agar selain (up to date) juga tidak kehilangan daya tarik.

\section{DAFTAR PUSTAKA}

Annisah, Siti. 2014. Alat Peraga Pembelajaran Matematika. Jurnal Tarbawiyah, 11(1): 1-15. Online. http://stainmetro.ac.id/ejournal/index.php/tarbawiyah/arti cle/download/297/283, diakses 26 Mei 2016

Arsyad, Azhar. 1996. Media Pembelajaran. Jakarta: Rajawali Pers.

Sri Rejeki,Anita. 2016. Pengembangan Perangkat Pembelajaran Menggunakan Model Pembelajaran Berbasis Masalah Untuk Meningkatkan Kemampuan Pemahaman Konsep Dan Disposisi Matematis Siswa SMP. Vox Edukasi, 7(2):111-125

Hutagaol, Anita Sri Rejeki dan Rismawati, Melinda. 2019. Penerapan Multimetode Untuk Meningkatkan Pemahaman Konsep Matematis Mahasiswa. J-Pimat. 1(1): 49-56.

Sudjana. 2011. Dasar-Dasar Proses Belajar Mengajar. Bandung: sinar baru algesindo.

. 2011. Penilaian Hasil Proses Belajar Mengajar. Bandung: Remaja Rosdakarya. 
Sugiyono. 2013. Metode Penelitian

Kuantitatif, Kualitatif dan $R \& D$.

Bandung: Alfabeta.

2013. Metode Penelitian Pendidikan.

Bandung: Alfabeta.

. 2014. Statistika Untuk Penelitian.

Bandung: Alfabeta.

Sukardi. 2003. Metodologi Penelitian

Pendidikan. Jakarta: Bumi Aksara.
Sundayana, Rostina. 2015. Media dan Alat Peraga dalam Pembelajaran Matematika. Bandung: Alfabeta, CV. 